\title{
GENOMIC SOVEREIGNTY OR THE ENEMY WITHIN
}

\author{
Jesús Mario Siqueiros-García ${ }^{1}$, Pablo Francisco Oliva-Sánchez ${ }^{1}$, Garbiñe Saruwatari-Zavala ${ }^{1}$
}

\begin{abstract}
Genomic sovereignty is a concept that has become very popular among developing countries such as India, China, South Africa and Mexico. This concept is a response to developed countries that have taken advantage of those countries and researchers who don't have the means for protecting their own biogenetic resources. In this article we argue that genomic sovereignty is not about the "others" extracting and exploiting local "human genetic resources", but developing and implementing the ethical, legal and administrative tools, based on transparency, openness and equal access to biological material, in order to build up a robust research networks. Being biological samples a scarce and valuable good, we conclude that controlling the access to this resource by means of the law, without a well implemented biobanking system and a clear scientific policy may lead to a situation where asymmetric relations are generated among research groups of the very same developing country. We would advice to those countries pretending to protect their biological samples and data from the outside, before developing laws against possible "intrusions", they need to design strategies to promote equal and fair access to both resources paramount to biomedical research.
\end{abstract}

Key words: genomic sovereignty, Mexico, law, research communities, developing countries, biological samples, cultural values, biobanks ethics

\section{Soberanía genómica o el enemigo interior}

Resumen: "Soberanía genómica" es un concepto que se ha hecho muy popular entre los países en desarrollo, como India, China, Sudáfrica y México. Este concepto es una respuesta a los países desarrollados que han tomado ventaja, aprovechándose de aquellos países y de los investigadores que no tienen los medios para proteger sus propios recursos biogenéticos. En este artículo argumentamos que la soberanía genética no se trata de impedir que "otros" extraigan y exploten "los recursos genéticos humanos" locales, sino del desarrollo y de la aplicación de las herramientas éticas, jurídicas y administrativas basadas en la transparencia, la apertura e igualdad en el acceso al material biológico, con el fin de construir redes de investigación sólidas. $\mathrm{Al}$ ser las muestras biológicas un bien escaso y valioso, concluimos que el control del acceso a este recurso, por medio de la ley, sin un sistema de biobancos bien implementado y sin una política científica clara, puede llevar a una relación asimétrica entre los grupos de investigación del mismo país en desarrollo. Nos gustaría advertir a los países que pretenden proteger sus muestras biológicas y datos asociados que, antes que elaborar leyes contra posibles intrusiones, es necesario diseñar estrategias para promover el acceso justo y equitativo a los recursos primordiales para la investigación biomédica.

Palabras clave: soberanía genómica, México, ley, comunidades de investigación, países en desarrollo, muestras biológicas, valores culturales, ética de biobancos

\section{Soberania genômica ou o inimigo interior}

Resumo: "Soberania genômica" é um conceito que se fez muito popular entre os países em desenvolvimento, como Índia, China, África do Sul e México. Este conceito é uma resposta aos países desenvolvidos que obtiveram vantagem, aproveitandose daqueles países e dos investigadores que não têm meios para proteger os seus próprios recursos biogenéticos. Neste artigo argumentamos que a soberania genética não trata de impedir que "outros" extraiam e explorem "os recursos genéticos humanos" locais, senáo do desenvolvimento e da aplicaçáo das ferramentas éticas, jurídicas e administrativas baseadas na transparência, abertura e igualdade no acesso ao material biológico, com a finalidade de construir redes de investigação sólidas. Por serem as amostras biológicas um bem escasso e valioso, concluimos que o controle do acesso a este recurso, por meio da lei, sem um sistema de biobancos bem implementado e sem uma política científica clara, pode levar a uma relação assimétrica entre os grupos de investigação de um mesmo país em desenvolvimento. Gostaríamos advertir aos países que pretendem proteger suas amostras biológicas e dados associados que, antes de elaborar leis contra possíveis intromissões, é necessário projetar estratégias para promover o acesso justo e equitativo aos recursos primordiais para a investigação biomédica.

Palavras-chave: soberania genômica, México, lei, comunidades de investigação, países em desenvolvimento, amostras biológicas, valores culturais, ética de biobancos

\footnotetext{
${ }^{1}$ Departamento de Estudios Jurídicos, Éticos y Sociales (EJES), Instituto Nacional de Medicina Genómica (INMEGEN), México Correspondence: jsiqueiros@inmegen.gob.mx
} 


\section{Introduction}

"Genomic sovereignty is the capacity of a people, a country or nation to own, to control both access to and use of, samples, data and knowledge concerning or emanating from genomic material"(1). This is a broad definition and it reflects the essence of the idea. Altogether, it is important to mention too, that this is a concept that emerges from those who feel the need to protect their biogenetic resources from third parties to exploit them.

Acknowledging such nuances, genomic sovereignty is a concept that is popular among certain countries and some of them are pursuing it, or at least that is what could be perceived during the $12^{\text {th }}$ International Congress of Human Genetics that took place in Montreal last October. Dr. Charles Rotimi, one of the most prominent promoters of Genomics in Africa, emphasized the importance of it in Africa by means of the control of access of biological samples and data. $\mathrm{He}$ mentioned India, China and Mexico as those countries who had already implemented it and the latter as leader in this subject.

For Mexico, genomic sovereignty discourse had a first order role in promoting among congressmen and in convincing them about the importance of the Genomic Medicine Project, including the creation of the National Institute of Genomic Medicine. One day after Dr. Rotimi's presentation, in the same Congress we gave a talk about Mexico's quirks with its legal framework regarding genomic sovereignty. With this subject in mind, in this article our main argument is that for Mexico and probably for other developing countries, genomic sovereignty is not about 'others' extracting and exploiting local resources regardless the sovereignty of the local, but about local scientific communities cultural and moral values and the capacity to build a strong research network to exploit (biological samples) national resources.

\section{Historical review}

In 1999, ten years after the Human Genome Project was launched, four Mexican institutions started working together on the Genomic Medicine and National Institute of Genomics project.
This group included the Ministry of Health (SS), the National Council of Science and Technology (CONACyT), the National Autonomous University of Mexico (UNAM), and the Foundation of Health (FUNSALUD). By 2001, it was known as the Consortium to Promote Genomic Medicine. By 2004 the National Institute of Genomic Medicine was born and in 2008, the Mexican Senate discussed and added an amendment to the General Health Act (GHA), regarding the protection of biogenetic material from being transferred out of Mexico.

Since the very beginning of the project, the Consortium considered vital to gain control over the Mexican genetic diversity as a "natural resource" by means of a legal instrument. Nevertheless, it was until 2008 that a legal instrument became a real necessity due to situations in which DNA samples were taken out of the Country without Mexico being part of those projects or without consent by the Mexican authorities(2).

The argument in favor of the protection of the Mexican unique genetic profile persuaded congressmen to work on a set of amendments to the GHA, that without being a Law are known as the Genomic Sovereignty Law. The concept of sovereignty is well rooted in the Mexican nationalistic discourse and it's linked to a postcolonial stance. The protection of biological samples was justified to the congressmen by saying that being the Mexican population genetically different, we wouldn't be able, as a country to import genomic medicine based on others populations genetic profile, and still, this genetic profile is valuable for research. Outstanding to all justifications was the idea of giving an ideological value to the Mexican genetic uniqueness by means of the identity discourse of the mestizo(2-5).

The Genomic Sovereignty Law had the intention to prevent outsiders of taking advantage of the "natural resources" as it had been done in the past in Mexico's history (some examples such as petroleum, archaeological exploration and the use of biodiversity resources by multinational industries were cited) by regulating access to human biological samples, all of this under the premise that the Mexican genome had to be studied by and for Mexicans (primarily)(5). 
According to the Mexican Law, a natural resources is a natural element that can be exploited for the benefit of $\operatorname{man}(6)$. But as such, in the context of the stakeholders discourse, the Mexican population's genetic material was conceived as a "national good", that is, as a natural resource that would belong to Mexico, that cannot be privatized by anyone or only under very specific circumstances, and that its use and exploitation should benefit all Mexicans.2 This way of conceiving the genetic material of the Mexican population would go very well along with the already existing discourse of Mexico's Sovereignty.

Under this vision of genomic sovereignty, in 2008, congressmen approved the genomic sovereignty amendments to the GHA that established that genomics studies must be part of a scientific research project, that biological samples, intended for population Genomic studies, can't be transferred out of Mexico if it is not part of a Mexican scientific project, and finally, that anyone who takes biological samples (from which DNA can be extracted for population genomics studies) will be sanctioned with prison and a fine(7).

The problem as we see it, was that while focusing on the control over biological samples, congressmen and stakeholders didn't acknowledge the complexities of the genomic enterprise and ignore its social, economical, and political dimensions. They failed in developing the right policies to accomplish the desired sovereign scientific project because access to samples and data could escape by so many different ways, legal and factual. So far, the LGS is non-operative due to the absence of the administrative instruments to apply it. Still, there is more, the legal status of biological samples is not clear and they fit in more than one legal category in the Mexican legal frame, for example samples can be a national good where, again it fits in different overlapping concepts such as common good, State goods, goods for public service of the State, moveable property, private property. Biological samples can be conceptua-

\footnotetext{
${ }^{2}$ The sovereignty discourse has an excellent example in the case of petroleum as a national resource on which Mexico is sovereign. In 1938, President Cardenas expropriated the oil from foreign companies (American, British, and Dutch), since then, it has been a motive of proud Mexico's sovereignty over its petroleum, as well as a taboo among congressmen and possible Mexican stakeholders to propose to open the Mexican state-owned petroleum company to foreign investment.
}

lized as a natural resource, where human DNA could be part of the country's biodiversity. In Mexico's legal frame, there is no reference to the possible research, clinical, forensic, parental tests and economical use of samples. In this regard we believe that the legal fuzziness of biological samples makes control over genetic diversity a fuzzy matter.

\section{Discussion}

From our experience, genomic sovereignty is not about the control over biological samples, but about having the tools to exploit these resources. By tools we refer not only to the necessary technologies for whole genome sequencing, exome sequencing, mRNA (transcriptome), etcetera, instead, we are talking about developing and implementing the ethical, legal and administrative tools for building up a robust research network. For those countries claiming sovereignty (most of them developing countries), robustness must be designed to get the more from the less by means of transparency, openness, inside network preferential cooperation, and network exchange of samples and data, software and knowledge (reproducible experiments and reports).

It has been said so many times that genomic sovereignty is about preventing the exploitation of one country's populations samples by developed countries research institutions based on a asymmetrical relationship which leads to an unfair, unjust situation for the 'donor' country. As once said by a group of Mexican researchers at the very beginning of the Mexican Genomic Medicine Project:

"It is urgent to issue a legislation that allows the gene pool of Mexican populations to be studied through cutting edge technologies in our country and by national researchers. Our populations, isolated and highly related and very genetically homogeneous, allow the isolation and identification of disease genes more easily. Therefore, high priority should be given to the collection and study of Mexican germplasm by scientists of our country, without prejudice to international collaborations, preventing this national resource to be studied, classified and used almost exclusively by researchers from other countries like has 
happened in the past, for example, in archeology, wildlife and flora"(5).

For Aréchiga and collaborators the problem is quite clear and it seems that is the same problem for the countries interested in protecting their population's DNA. As it has been mentioned elsewhere, this is a postcolonial matter, it's about not letting others who have, traditionally, been taking advantage of those who don't have the means for protecting their resources as well as themselves $(2,4)$.

Our point of view regarding genomic sovereignty is that it is not (at least primarily) about those researchers and their institutions coming from a wealthy Country trying to get all what they can from poor countries, with a sloppy and weak legislation that makes them vulnerable. What we propose is that, even if it is important to set rules on how international collaborations are to take place, the main problem may lay inside the national research communities.

The Mexican Genomic Sovereignty Law so far is not operative because the administrative and institutional procedures have not been developed and implemented yet. In order for Mexican researchers to keep collaborating with overseas institutions they have had to look for other 'legal' ways to go around the limitations imposed by this situation. Looking for other 'legal' options to skip the problems posed by the current state legislation on genomic sovereignty might lead to malpractice regarding biological samples management and to research malpractice as well, not to mention that genomic sovereignty might be at stake and it becomes a second order concern, making the Law irrelevant.

We suggest that lawmakers should be focused in the creation of the legal instruments to develop strong research networks. We also suggest that research networks are not only a matter of law and policies; in order to generate such networks, it is necessary to understand what are the dominant moral and cultural values as well as its practices in scientific communities. It would be very important to understand how those values and practices emerge, and what is the role they play in articulating or fragmenting research commu- nities. Culture (values and practices) may play a big part in developing a robust research network and making genomic sovereignty real (if that is what really matters). It is about the importance of cooperation, so it is paramount to know if sharing and exchanging data is relevant, what are the factual rules for sharing and exchanging biological samples and data, and who cooperates with who and why.

What is at stake here is that controlling biological samples by means of the Law, without a previously well implemented biobanking system and a clear scientific policy, can lead to a bigger problem than what it pretends to prevent, for example, biological samples are absolutely necessary for genomics research and they are also a scarce good, for which they can be an object that generates power asymmetry relations among research groups. Regarding data, as far as we know, it is out of reach of genomic sovereignty domain, but what would a biological sample be if not the locus of information. Data needs to be shared preferentially among the research networks.

\section{Final remarks}

What can be learned from the Mexico's genomic sovereignty project experience is that instead of trying to develop a Genomics research system based on the control over one simple object, the strategy should start acknowledging that the Genomic enterprise is complex:

- It involves different omic approaches (and is not only about population genomics).

- There are different ends of the omic approaches (health, research, forensics, economical, educational).

- The meaning of concepts change in different contexts (scientific, legal, commercial, ethical, healthcare, etcetera, to mention them in the broadest sense).

- Social dynamics of Science are important (imply epistemic, moral and ethical, social values).

- There are Ethical, Legal and Social issues of science that have an impact on society and 
that need to be taken into account.

To those countries pretending to protect their biological samples and data from the outside, we would say that before developing laws against possible 'intrusions', they need to design strategies to promote equal and fair access to both samples an data. Unfair and unequally access to them promotes the entrenchment of power relationships among local research groups, but, to the worse, it allows the entrenchment of certain cultural practices in scientific communities, making more difficult to change them into good practices. Power disparities may also lead powerful groups to increase their power, for example, groups with preferential access to biological samples might be the ones with the possibility of establishing part- nerships with important research groups from developed countries. Preventing the dominance of some research groups over samples would be the first step in building a strong research network. Our final statement is that wrongly designed and implemented laws affecting scientific research somehow, may lead to scientific malpractice.

\section{Acknowledgments}

We wish to thank Dr. Sergio Litewka for his comments and suggestions. Support from the Pan American Bioethics Initiative, Fogarty International Center-NIH \#1R25TW008186 is gratefully acknowledged.

References

1. Slabbert MN, Pepper MS: "A room of our own?” Legal lacunae regarding genomic sovereignty in South Africa. Tydskrif vir Hedendaagse Romeins-Hollandse Reg. Journal of Contemporary South African Roman-Dutch Law 2010; 73: 432-450.

2. Schwartz-Marín E. Protegiendo el "Mextizaje": INMEGEN y la Construcción de la Soberanía Genómica. In LópezBeltrán C, (ed.) Genes (\&) Mestizos. UNAM-IIF, Editorial Ficticia; 2011: 155-184.

3. Schwartz-Marín E, Silva-Zolezzi I. The Map of the Mexican's Genome: Overlapping National Identity, and Population Genomics. Identity in the Information Society 2010; 3(3): 489-514.

4. Benjamin R. A lab of their own: Genomic sovereignty as postcolonial science policy. Policy and Society 2009; 28: 341355.

5. Aréchiga $\mathrm{H}$, et al. El proyecto del genóma humano: perspectivas de la medicina genómica. Rev Fac Med UNAM 2000; 43(5): 202-205.

6. México. Cámara de Diputados del H. Congreso de la Unión. Ley General del Equilibrio Ecológico y la Protección al Ambiente. Diario Oficial de la Federación, 28 de enero de 1988.

7. México. Cámara de Diputados del H. Congreso de la Unión. Decreto por el que se reforma la fracción V del artículo 100 y el artículo 461, y se adicionan los artículos 317 Bis y 317 Bis 1, todos de la Ley General de Salud. Diario Oficial de la Federación, 14 de julio de 2008.

Received: March 21, 2012

Accepted: May 23, 2012 